\title{
PENTINGNYA AUDIT SISTEM INFORMASI BAGI ORGANISASI
}

\author{
TRI HAMSAH \\ 165100084 \\ Fakultas Komputer \\ trihamsah.student@umitra.ac.id
}

\begin{abstract}
Perkembangan teknologi telah mengakibatkan perubahan pengolahan data yang dilakukan perusahaan dari sistem manual menjadi secara mekanis, elektromekanis, dan selanjutnya ke sistem elektronik atau komputerisasi. Peralihan ke sistem yang terkomputerisasi memungkinkan data yang kompleks dapat diproses dengan cepat dan teliti, guna menghasilkan suatu informasi. Dalam mendukung aktivitas sebuah organisasi, informasi menjadi bagian yang sangat penting baik untuk perkembangan organisasi maupun membaca persaingan pasar. Dalam hal proses data menjadi suatu informasi merupakan sebuah kegiatan dalam organisasi yang bersifat repetitif sehingga harus dilaksanakan secara sistematis dan otomatis.
\end{abstract}

Kata Kunci : pentingnya audit sistem informasi bagi organisasi 


\section{A. PENDAHULUAN}

Materi Kuliah Membahas Tentang Pengantar Struktur Data membahas mengenai i cloud system ...dst tambahkan gambar untuk memperkuat penjelasan ( Gunakan Minimal 400 kata )।

\section{JAWAB:}

Menurut Weber (1999) terdapat beberapa alasan mendasar mengapa organisasi perlu melakukan audit sebagai evaluasi dan pengendalian terhadap sistem yang digunakan oleh organisasi :

\section{Pencegahan terhadap biaya organisasi untuk data yang hilang}

Kehilangan data dapat terjadi karena ketidakmampuan pengendalian terhadap pemakaian komputer. Kelalaian dengan tidak menyediakan backup yang memadai terhadap file data, sehingga kehilangan file dapat terjadi karena program komputer yang rusak, adanya sabotase, atau kerusakan normal yang membuat file tersebut tidak dapat diperbaiki sehingga akhirnya membuat kelanjutan operasional organisasi menjadi terganggu.

\section{Pengambilan keputusan yang tidak sesuai}

Membuat keputusan yang berkualitas tergantung pada kualitas data yang akurat dan kualitas dari proses pengambilan keputusan itu sendiri. Pentingnya data yang akurat bergantung kepada jenis keputusan yang akan dibuat oleh orang - orang yang berkepentingan di suatu organisasi.

\section{Penyalahgunaan komputer}

Penyalahgunaan komputer memberikan pengaruh kuat terhadap pengembangan EDP audit maka untuk dapat memahami EDP audit diperlukan pemahaman yang baik terhadap beberapa kasus penyalahgunaan komputer yang pernah terjadi.

\section{Nilai dari perangkat keras komputer, perangkat lunak dan personel}

Disamping data, hardware dan software serta personel komputer juga merupakan sumber daya yang kritikal bagi suatu organisasi, walaupun investasi hardware perusahaan sudah dilindungi oleh asuransi, tetapi kehilangan hardware baik terjadi karena kesengajaan maupun ketidaksengajaan dapat mengakibatkan gangguan. Jika software rusak akan mengganggu jalannya operasional dan bila software dicuri maka informasi yang rahasia dapat dijual kepada kompetitor. Personel adalah sumber daya yang paling berharga, mereka harus dididik dengan baik agar menjadi tenaga handal dibidang komputer yang profesional.

\section{Biaya yang tinggi untuk kerusakan komputer}

Saat ini pemakaian komputer sudah sangat meluas dan dilakukan juga terhadap fungsi kritis pada kehidupan kita. Kesalahan yang terjadi pada komputer memberikan implikasi yang luar biasa, sebagai contoh data error mengakibatkan jatuhnya pesawat di Antartika yang menyebabkan 257 orang meninggal atau seseorang divonis masuk 
penjara karena kesalahan data di komputer.

\section{Kerahasiaan}

Banyak data tentang diri pribadi yang saat ini dapat diperoleh dengan cepat, dengan adanya komputerisasi kependudukan maka data mengenai seseorang dapat segera diketahui termasuk hal - hal pribadi.

\section{Pengontrolan penggunaan komputer}

Teknologi adalah hal yang alami, tidak ada teknologi yang baik atau buruk. Pengguna teknologi tersebut yang dapat menentukan apakah teknologi itu akan menjadi baik atau malah menimbulkan gangguan. Banyak keputusan yang harus diambil untuk mengetahui apakah komputer digunakan untuk suatu hal yang baik atau buruk.

\section{B. PEMBAHASAN / STUDI KASUS}

Anda Boleh menjelaskan ( Baca: Hal yang akan anda paparkan pada bagian content ini ) ; ex:Materi $\mathrm{Ke} 1$ membahas mengenai i cloud system ...dst tambahkan gambar untuk memperkuat penjelasan ( Gunakan Minimal 600 kata ) \& ID Secuity \& Reference dibawah Tidak Boleh Dirubah

\section{JAWAB:}

pada saat ini teknologi semakin berkembang, sehingga dapat memudahkan penggunanya untuk melakukan segala aktifitas. Salah satunya adalah melakukan Audit SI. Karena dengan menggunakan teknologi komputerisasi data yang diolah akan menjadi lebih baik lagi hasilnya. Beberapa alasan mengapa Audit SI penting untuk dilakukan adalah sebagai berikut :

1. Kerugian akibat kehilangan data Informasi berasal dari suatu data yang diolah dan memiliki manfa'at bagi penggunanya. Oleh karena itu, data adalah suatu aset yang penting bagi suatu perusahaan atau organisasi. Informasi dari suatu data akan menjadi gambaran dari kondisi di masa lalu, sekarang, dan masa yang akan datang. Jika informasi dari data tersebut hilang, maka akan menyebabkan suatu kesalahan yang fatal.

\section{Kesalahan dalam pengambilan keputusan}

Saat ini masih banyak instansi yang menggunakan perangkat lunak dalam mengambil keputusan. Namun, resiko yang ditimbulkan bisa saja bukan lagi membahayakan sistem, tetapi juga dapat membahayakan nyawa seseorang seperti dalam penggunaan DSS (Sistem Penunjang Keputusan) dalam bidang kedokteran. Tingkat akurasi dan pentingnya suatu data tergantung kepada jenis keputusan yang akan diambil.

\section{Kerugian yang disebabkan oleh kesalahan pemrosesan komputer Banyak organisasi atau perusahaan yang telah menggunakan komputer sebagai sarana untuk meningkatkan kualitas pekerjaan mereka. Mulai dari hal yang sederhana, pernghitungan bunga dalam jumlah besar, dan juga navigasi pesawat}


terbang atau peluru kendali. Kerugian tersebut dapat pula berupa kebocoran data dan dapat menimbulkan dampak yang akan merugikan bagi suatu perusahaan atau organisasi seperti kehilangan klien, pelanggan, perhitungan matematis yang sulit dipercaya, dan juga dapat menggangu kelangsungan hidup perusahaan.

\section{Penggunaan komputer yang di salah gunakan}

Tingginya tingkat penyalahgunaan komputer menjadi salah satu alasan mengapa audit sistem informasi diperlukan. Banyak sekali pihak yang tidak bertanggungjawab dapat melakukan kejahatan komputer seperti Hacker, Cracker dan Virus.

a) Hacker : Merupakan seseorang yang dengan sengaja masuk ke dalam suatu sistem tanpa izin. Mereka melakukan hal tersebut biasanya hanya untuk membuat dirinya sendiri atau kelompoknya bangga karena telah berhasil menembus sistem keamanan dari suatu perusahaan atau organisasi, tanpa ada maksud untuk merusak atau mengambil sesuatu atas apa yang telah dilakukan.

b) Cracker : Cracker memasuki suatu sistem yang memiliki tujuan untuk mengambil keuntungan sebanyakbanyaknya seperti mengubah, merusak, atau bahkan menghancurkan sistem tersebut.

c) Virus : Merupakan sebuah program komputer yang melekatkan diri dan menjalankan dirinya sendiri pada suatu data. Virus meriplikasi dirinya sendiri secara aktif dan mengganggu atau merusak suatu sistem operasi, data, dan bahkan mengacaukan sistem.
Kejahatan komputer juga dapat dilakukan oleh karyawan yang merasa tidak puas dengan kebijaksanaan perusahaan, baik yang masih bekerja, sudah berhenti, keluar, diberhentikan dari perusahaan tersebut dan bahkan yang pindah bekerja ke perusahaan lain. Dan hal tersebut dilakukan untuk memperoleh keuntungan atau manfaat dalam bersaing. Oleh karena itu audit sangat diperlukan dan terdapat dua hal utama yang harus diperhatikan pada saat melakukan audit atau pemrosesan data elektronik seperti pengumpulan bukti dan evaluasi bukti.

\section{Kesalahan pada proses perhitungan} Sistem Informasi sering digunakan untuk melakukan proses menghitung yang rumit karena memiliki kemampuan untuk mengolah data secara tepat dan akurat, namun juga menimbulkan resiko kesalahan. Tanpa adanya pengembangan sistem yang baik, tentu saja dapat terjadi kesalahan menghitung dan yang lebih buruk adalah sistem yang baru yang sudah dibuat akan sulit di deteksi tanpa ada proses audit yang dilakukan.

\section{Nilai investasi yang tinggi untuk perangkat keras dan perangkat lunak komputer}

Investasi yang dikeluarkan suatu perusahaan tentu sangat besar dan sulit untuk mengukur manfaat yang dapat diberikan oleh suatu sistem atau teknologi informasi.

\section{ID SECURITY QWTD4452377-ASP-5244107}

\section{KESIMPULAN}

Kesimpulan dari materi ini adalah ....( minimal 150 kata ) 


\section{JAWAB}

Audit system informasi bagi organisasi adalah suatu sistem yang menyediakan data maupun informasi yang berkaitan dengan pelaksanaan tugas-tugas organisasi kepada pengelola organisasi atau bisa juga dikatakan bahwa Sistim Informasi Manajemen merupakan suatu sistem formal tentang pelaporan, penggolongan dan penyebaran informasi kepada orangorang yang tepat dalam suatu organisasi. Lebih lengkapnya SIM adalah jaringan prosedur pengolahan data yang dikembangkan dalam organisasi dengan maksud memberikan data kepada manajemen setiap waktu diperlukan, baik data yang bersifat intern maupun yang bersifat ekstern, untuk dasar pengambilan keputusan dalam rangka mencapai tujuan organisasi. Dengan demikian Sistim Informasi Manajemen yang sudah maju tidak hanya mengerjakan fungsi tata usaha akan tetapi juga memberikan bantuan pengambilan keputusan kepada manajemen. Dengan SIM kegiatan organisasi yang berupa pelaporan dapat di standarisasi, dibuat prosedurnya dan dijadwalkan, sehingga sistem pelaporan akan memberikan data yang cermat, tepat waktu dan yang mempunyai makna bagi perencanaan, analisis/ pengorganisasian dan pengendalian manajemen untuk mengoptimalkan pertumbuhan organisasi, serta proses tersebut dapat dilakukan secara hemat.

Supaya informasi yang dihasilkan oleh sistem informasi dapat berguna bagi manajamen, maka analis sistem harus mengetahui kebutuhankebutuhan informasi yang dibutuhkannya, yaitu dengan mengetahui kegiatan-kegiatan untuk masing-masing tingkat (level) manajemen dan tipe keputusan yang diambilnya. Berdasarkan pada pengertian-pengertian di atas, maka terlihat bahwa tujuan dibentuknya Sistem Informasi Manajemen atau SIM adalah supaya organisasi memiliki informasi yang bermanfaat dalam pembuatan keputusan manajemen, baik yang meyangkut keputusan-keputusan rutin maupun keputusan-keputusan yang strategis. Sehingga SIM adalah suatu sistem yang menyediakan kepada pengelola organisasi data maupun 
informasi yang berkaitan dengan pelaksanaan tugas-tugas organisasi.

dapat disimpulkan bahwa Audit Sistem Informasi adalah proses pengumpulan dan pengevaluasian buktibukti untuk membuktikan dan menentukan apakah sistem aplikasi komputerisasi yang digunakan telah menetapkan dan menerapkan sistem pengendalian intern yang memadai, apakah aset organisasi sudah dilindungi dengan baik dan tidak disalah gunakan, apakah mampu menjaga integritas data, kehandalan serta efektifitas dan efisiensi penyelenggaraan sistem informasi berbasis komputer.

Konteks dalam proses audit sistem informasi ini terbagi menjadi 3 yaitu audit sistem informasi berbasis risiko, audit sistem informasi berbasis kendali, audit sistem informasi berbasis komputer.

\section{E. DISKUSI}

Saya bersama teman saya bernama Rudi mendiskusikan tentang contoh ini dengan sangat baik Hasil diskusi dari materi ini adalah ....( minimal 150 kata $)$

Menurut saya terdapat empat tujuan utama mengapa perlu dilakukannya audit sistem informasi yaitu:

\section{(1) Mengamankan asset}

Asset (aktiva) yang berhubungan dengan instalasi sistem informasi mencakup: perangkat keras, perangkat lunak, fasilitas, manusia, file data, dokumentasi sistem, dan peralatan pendukung lainnya. Sama halnya dngan aktiva aktiva lainnya, maka aktiva ini juga perlu dilindungi dengan memasang pengendalian internal. Perangkat keras bisa rusak karena unsur kejahatan ataupun sebab-sebab lain. Perangkat lunak dan isi file data dapat dicuri. Peralatan pendukung dapat dihancurkan atau digunakan untuk tujuan yang tidak diotorisasi. Karena konsentrasi aktiva tersebut berada pada lokasi pusat sistem informasi, maka pengamanannya pun menjadi perhatian dan tujuan yang sangat penting.

(2) Menjaga integritas data

Integritas data merupakan konsep dasar audit sistem informasi. Integritas data berarti data memiliki atribut: kelengkapan (completeness), sehat dan jujur (soundness), kemurnian (purity), ketelitian (veracity). Tanpa menjaga integritas data, organisasi tidak dapat memperlihatkan potret dirinya dengan benar akibatnya, keputusan maupun langkahlangkah penting di organisasi salah sasaran karena tidak didukung dengan data yang benar.

\section{(3) Menjaga efektivitas sistem}

Sistem informasi dikatakan efektif hanya jika sistem tersebut dapat mencapai tujuannya. Untuk menilai efektivitas sistem, auditor sistem informasi harus tahu mengenai kebutuhan pengguna sistem atau pihakpihak pembuat keputusan yang terkait dengan layanan sistem tersebut. Selanjutnya, untuk menilai apakah sistem 
menghasilkan laporan / informasi yang bermanfaat bagi penggunanya, auditor perlu mengetahui karakteristik user berikut proses pengambilan keputusannya.

(4) Mencapai efisiensi sumber daya

Suatu sistem sebagai fasilitas pemrosesan informasi dikatakan efisien jika ia menggunakan sumber daya seminimal mungkin untuk menghasilkan output yang dibutuhkan. Efisiensi sistem pengolahan data menjadi penting apabila tidak ada lagi kapasitas sistem yang menganggur.

Dari alasan dan tujuan tersebut sangat jelas bahwa penting bagi sebuah organisasi untuk melakukan audit sistem informasi guna melihat kembali apakah sistem yang berjalansudah tepat dan terpenting sistem mampu untuk mendukung tercapainya tujuan organisasi.

Terlihat mudah namun percaya atau tidak penulis menemukan masih banyak organisasi yang belum dengan secara konsisten melakukan audit serta evaluasi terhadap sistem yang digunakan meskipun secara sadar bahwa investasi yang ditanamkan tidak dalam jumlah yang kecil, namun ironisnya yang justru terjadi adalah audit dan evaluasi baru mulai secara rutin dilakukan setelah organisasi merasakan resiko dan baru mulai mencari tahu penyebabnya.

Sedari dini, mulailah untuk dengan seksama melakukan penilaian terhadap sistem yang digunakan agar tujuan awal investasi tidak menjadi sia - sia.

\section{F. REFERENCE}

[1] O. M. Febriani and A. S. Putra, "Sistem Informasi Monitoring Inventori Barang Pada Balai Riset Standardisasi Industri Bandar Lampung," J. Inform., vol. 13, no. 1, pp. 90-98, 2014.

[2] A. S. Putra, "Paperplain: Execution Fundamental Create Application With Borland Delphi 7.0 University Of Mitra Indonesia," 2018.

[3] A. S. Putra, "2018 Artikel Struktur Data, Audit Dan Jaringan Komputer," 2018.

[4] A. S. Putra, "ALIAS MANAGER USED IN DATABASE DESKTOP STUDI CASE DB DEMOS."

[5] A. S. Putra, "COMPREHENSIVE SET OF PROFESSIONAL FOR DISTRIBUTE COMPUTING."

[6] A. S. Putra, "DATA ORIENTED RECOGNITION IN BORLAND DELPHI 7.0."

[7] A. S. Putra, "EMBARCADERO DELPHI XE 2 IN GPUPOWERED FIREMONKEY APPLICATION."

[8] A. S. Putra, "HAK ATAS KEKAYAAN INTELEKTUAL DALAM DUNIA TEKNOLOGY BERBASIS REVOLUSI INDUSTRI 4.0."

[9] A. S. Putra, "IMPLEMENTASI PERATURAN 
PERUNDANGAN UU. NO 31 TAHUN $2000 \quad$ TENTANG DESAIN INDUSTRI BERBASIS INFORMATION TECHNOLOGY."

[10] A. $\mathrm{S}$. "IMPLEMENTATION PARADOX DBASE."

[11] A. A. S. Putra,

Putra, OF "IMPLEMENTATION OF TRADE SECRET CASE STUDY SAMSUNG MOBILE PHONE."

[12] A. S. Putra, "IMPLEMENTATION PATENT FOR APPLICATION WEB BASED CASE STUDI WWW. PUBLIKLAMPUNG. COM." A. S. Putra, "IMPLEMENTATION SYSTEM FIRST TO INVENT IN DIGITALLY INDUSTRY."

[14] A. S. Putra, "MANUAL REPORT \& INTEGRATED DEVELOPMENT

ENVIRONMENT BORLAND DELPHI 7.0."

[15] A. S. Putra, "PATENT AS RELEVAN SUPPORT RESEARCH."

[16] A. S. Putra, "PATENT FOR RESEARCH STUDY CASE OF APPLE. Inc."

[17] A. S. Putra, "PATENT PROTECTION FOR APPLICATION INVENT."

[18] A. S. Putra, "QUICK REPORT IN PROPERTY PROGRAMMING."

[19] A. S. Putra, "REVIEW CIRCUIT LAYOUT COMPONENT REQUIREMENT ON ASUS NOTEBOOK."

[20] A. S. Putra, "REVIEW TRADEMARK PATENT FOR INDUSTRIAL TECHNOLOGY
BASED 4.0."

[21] A. S. Putra, "TOOLBAR COMPONENT PALLETTE IN OBJECT ORIENTED PROGRAMMING."

[22] A. S. Putra, "WORKING DIRECTORY SET FOR PARADOX 7."

[23]

A. S. Putra, "ZQUERY CONNECTION

IMPLEMENTED

PROGRAMMING STUDI CASE PT. BANK BCA Tbk."

[24] A. S. Putra, D. R. Aryanti, and I. Hartati, "Metode SAW (Simple Additive Weighting) sebagai Sistem Pendukung Keputusan Guru Berprestasi (Studi Kasus: SMK Global Surya)," in Prosiding Seminar Nasional Darmajaya, 2018, vol. 1, no. 1, pp. 85-97.

[25] A. S. Putra and O. M. Febriani, "Knowledge Management Online Application in PDAM Lampung Province," in Prosiding International conference on Information Technology and Business (ICITB), 2018, pp. 181187.

[26] A. S. Putra, O. M. Febriani, and B. Bachry, "Implementasi Genetic Fuzzy System Untuk Mengidentifikasi Hasil Curian Kendaraan Bermotor Di Polda Lampung," SIMADA (Jurnal Sist. Inf. dan Manaj. Basis Data), vol. 1, no. 1, pp. 21-30, 2018.

[27] A. S. Putra, H. Sukri, and K. Zuhri, "Sistem Monitoring Realtime Jaringan Irigasi Desa (JIDES) Dengan Konsep Jaringan Sensor Nirkabel," IJEIS (Indonesian J. Electron. Instrum. Syst., vol. 8, no. 2, pp. 221-232. 
TUGAS 2 - 88675543

[28] D. P. Sari, O. M. Febriani, and A. S. Putra, "Perancangan Sistem Informasi SDM Berprestasi pada SD Global Surya," in Prosiding Seminar Nasional Darmajaya, 2018, vol. 1, no. 1, pp. 289-294. 